\title{
Systemic Evaluation of Mechanism of Cytotoxicity in Human Colon Cancer HCT-116 Cells of Silver Nanoparticles Synthesized Using Marine Algae Ulva Lactuca Extract.
}

\section{Diptikanta Acharya ( $\nabla$ dacharya249@gmail.com )}

GIET University https://orcid.org/0000-0002-3615-8200

\section{Sagarika Satapathy}

GIET University

Kanti Kusum Yadav

Karunya Institute of Technology and Sciences

\section{Prathap Somu}

Karunya Institute of Technology and Sciences

\section{Gitanjali Mishra}

Berhampur University

\section{Research Article}

Keywords: Silver Nanoparticles, Biogenic, Colon cancer, Apoptosis, Nucleus fragmentation and condensation

Posted Date: August 26th, 2021

DOI: https://doi.org/10.21203/rs.3.rs-830011/v1

License: (c) (i) This work is licensed under a Creative Commons Attribution 4.0 International License.

Read Full License

Version of Record: A version of this preprint was published at Journal of Inorganic and Organometallic Polymers and Materials on October 21st, 2021. See the published version at https://doi.org/10.1007/s10904-021-02133-8. 


\section{Abstract}

In the current study, biogenic silver nanoparticles (U-AgNPs) were synthesized using marine green macroalgal Ulva Lactuca extract, and evaluated mechanism behind the anticancer activity against the Human colon cancer (HCT-116). The novel biogenic U-AgNPs were characterized using various physiochemical techniques. The TEM micrographs confirmed the spherical morphology of synthesized U-AgNPs, with a mean size of 8-14 nm. FTIR Spectra analysis of U-AgNPs confirmed Ulva Lactuca extract bioactive molecules presence over U-AgNPs surface as a stabilizing agent, thereby improving biocompatibility. The cytotoxicity study revealed the dose dependent cell death in colon cancer cells with no loss of viability in normal human colon epithelial cells. Furthermore, the fluorescence micrographs of nucleus staining assay revealed the DNA fragmentation and nucleus condensation of cancer cells treated with U-AgNPs, indicating an apoptosis-mediated cell death. The western bolt and RT-PCR analysis of U-AgNPs treated cancer cells showed the rise in proapoptotic markers (P53, Bax, and P21) and decline in anti-apoptotic markers (Bcl-2), thus confirming the p53-dependent apoptosis mediated cell death in HCT-116. Overall, our study concluded that novel biogenic U-AgNPs nanoparticles, synthesized using marine green macroalgal Ulva Lactuca extract showed efficient anticancer activity against HCT-116 cell line and hence could work as potential therapeutic agent for targeted anti-cancer therapy.

\section{Introduction}

Colorectal cancer is fourth among cancer-related deaths and the third commonly occurring malignancy amounting to up to $9.7 \%$ of all cancers as per the report of the International Agency for Research [1]. Reports have projected that colorectal cancer will spike up to 2.4 million by 2035 . The conventional method of the treatment of colorectal cancer is chemotherapy mainly employing fluoropyrimidine 5fluorouracil but suffers greatly by poor prognosis due to the side effects of chemotherapy and multi-drug resistance (MDR) as a consequence of low solubility and improper drug distribution [2, 3]. Hence, there is a need for alternative intervention having a better therapeutic index with minimal side effects.

In the recent decade, nanoparticles have gained a lot of attention in the field of cancer therapy as drug delivery agents, therapeutics, as well as in cancer diagnosis by imaging [4-7]. Importantly, metal nanoparticles have like silver nanoparticles (AgNPs) have distinctive properties comparatively whose exploitation has led to the breakthrough in various domains such as biomedical diagnostics [8], food industry [9], therapeutic agent [10,11], drug delivery [12], and antimicrobial agent [13-15].

Silver nanoparticles possess an advantage over other metal and metal oxide nanoparticles due to their intrinsic biological properties such as antimicrobial property, antioxidant property, anti-tumorigenic property, anti-inflammatory property $[4,16]$. These distinctive properties of silver nanoparticles become instrumental in utilizing them in different sectors as air and water disinfectant, biomedical applications like drug delivery process, wound healing patches, and medical devices, and most industries like textiles, food industry, and animal husbandry $[17,18]$. Moreover, silver nanoparticles have certain constraints for their biomedical application such as their undesirable toxicity and surface oxidation in an oxygen- 
containing biological fluid $[19,20]$. Constrains of AgNPs of undesirable cytotoxicity and surface oxidation can be curbed by capping the silver nanoparticle surface with biomolecules [21-23].

In this study, we synthesized novel biogenic silver nanoparticles (U-AgNPs) using extract of a green macro-algal Ulva Lactuca as green synthesis involved biomolecules as a reducing agent also acts as a capping agent helps in preventing undesirable cytotoxicity and surface oxidation. Further, the green synthesis provides an advantage over other methods by fabricating the nanoparticles with plant phytochemicals thus creating stable nanoparticle with uniform size [24, 25]. Further, the biogenic synthesized silver nanoparticle (U-AgNPs) characterized using Surface Plasmon Resonance (SPR) using UV-Vis spectrophotometer, XRD analysis (X-ray diffraction), Transmission electron microscopy (TEM), Energy-dispersive X-ray (EDX), FTIR, ろ-potential, and dynamic light scattering (DLS) analysis. Finally, the anticancer potential of U-AgNPs was studied in human colon cancer cells (HCT-116) using various cytochemical analyses as well as the cytocompatibility in human epithelial (FHC cells) and hemocompatibility (in human RBC cells) were also evaluated.

\section{Materials And Methods}

\subsection{Material}

High-quality grade Silver nitrate $\left(\mathrm{AgNO}_{3}\right)$ was obtained from Hi-media Ltd (Mumbai, India). All chemicals and DMEM media used in the current study were of analytical grade and procured from Sigma Aldrich (MO, USA). Buffers and sample preparation were prepared in double distilled water. The glassware used in the study were thoroughly washed, dried and sterilized. Antibodies used for analysis were procured from Cell Signalling Technology (MA, USA). All the cell lines used in the studied were procured from National Centre for Cell Science, Pune.

\subsection{Sample collection and preparation}

Ulva Lactuca commonly known as Sea lettuce were collected and cleaned thoroughly under running water. The cleaned plant leaves were rigorously grounded with mortar pestle to form a smooth paste using distilled water, which was then centrifuged at $3000 \mathrm{rpm}$ for $10 \mathrm{~min}$. The pellet was removed and supernatant was mixed vigorously with ethyl acetate in a ratio of 1:1 (v/v). This mixture was allowed to stand still for phase separation. Ethyl acetate phase containing bioactive molecule was collected and dried using a rotary evaporator. The Final concentrated Ulva Lactuca extract was stored at $4^{\circ} \mathrm{C}$ until further used.

\subsection{Synthesis and characterization of silver nanoparticles (U-AgNPs)}

AgNPs were synthesized using the concept of metal reduction by the plant extract at $25^{\circ} \mathrm{C}$. Here, $5 \mathrm{mM}$ aqueous $\mathrm{AgNO}_{3}$ solution $(100 \mathrm{ml})$ was taken in a Flask where the aqueous Ulva Lactuca Extract $(1 \mathrm{mg} / \mathrm{ml})$ is added dropwise with constant stirring until color of solution change to dark reddish/yellowish color 
indicating the formation of AgNPs. The preliminary confirmation of formation AgNPs was done using a UV-vis spectrophotometer (Perkin Elmer, I-35)., Transmission Electron microscopy (Joel-2800F) was done to further confirm the size and morphology of synthesized AgNPs with EDX. The size distribution and surface charge of the synthesized AgNPs was confirmed with dynamic particle size analyzer (Nano ZS, Malvern Instruments. An X-ray diffractometer (Rigaku - SmartLab) was performed to determine the crystallinity of the synthesized AgNPs. Further, FT-IR spectroscopy (Perkin Elmer, spectra-2) of biosynthesized AgNPs was carried out to study the chemical bond vibrations in AgNPs, to assure the presence of bioactive components or metabolites over its surface.

\subsection{Anticancer activity/cytotoxicity}

MTT (3-(4, 5-dimethylthiazol-2-yl)-2, 5-diphenyl tetrazolium bromide) assay was carried out to evaluate the anticancer activity of synthesized U-AgNPs. This method utilizes the principle of metabolization of tetrazolium salt in viable cells and which gives and absorbance at $570 \mathrm{~nm}$. In our study, we used colon cancer cell line HCT-116 and normal colon epithelial cells to study the cytotoxicity. The seeding of cells was done in a 96 well plate with the count of $5 \times 10^{4}$ cells/well, followed by the treatment of cells with varying U-AgNPs concentrations $(0-1000 \mu \mathrm{M})$ using DMEM media. The treated cells were then kept for incubation at $37^{\circ} \mathrm{C}$ for $24 \mathrm{~h}$ in a $\mathrm{CO}_{2}$ incubator with $5 \% \mathrm{CO}_{2}$ and $95 \%$ humidity conditions. Afterwards, the cell were again treated with MTT $(5 \mathrm{mg} / \mathrm{mL})$ and kept for further $4 \mathrm{~h}$. The crystals formed were dissolved in $200 \mu \mathrm{L}$ of DMSO and the absorbance was measured at $570 \mathrm{~nm}$ with a reference filter as $655 \mathrm{~nm}$.

\subsection{Nuclear Staining Assay}

In Brief, HCT-116 cells at a cell density of $2 \times 10^{5}$ viable cells per well were seeded in six-well plates and incubated in a $\mathrm{CO}_{2}$ incubator for $24 \mathrm{~h}$. After $24 \mathrm{~h}$ of incubation, culture media was replaced with a fresh medium containing U-AgNPs at the required concentration followed by incubation for $24 \mathrm{~h}$ with AgNPs. After the $24 \mathrm{~h}$ of treatment with U-AgNPs, cells were washed three times with cold PBS followed by cells staining using Hoechst 33342 dye $(10 \mu \mathrm{g} / \mathrm{mL})$ for $15 \mathrm{~min}$. Afterwards, the stained cells were visualized using a fluorescence microscope.

\subsection{RT-PCR analysis}

Total cell RNA was extracted from HCT-116 cells using Trizol Reagent (TRI reagent@, Sigma) as directed by manufacturer's procedure. The purified RNA was pellet stored in aliquots of $5 \mu$ in RNA storage buffer at $-80^{\circ} \mathrm{C}$ for further use. The cDNA first strand synthesis has been carried out using extracted RNA as template along with the oligo(dT)18 primer and reverse transcriptase (RevertAid ${ }^{\text {TM }} \mathrm{H}$ Minus First Strand cDNA Synthesis Kit). The cDNAs homologous of anti-apoptotic (Bcl-2) as well as pro-apoptotic markers (P53, Bax, and P21) and housekeeping gene (GAPDH) positive strand RNA were amplified for 30 cycles, using specific primers tabulated in Table 1. The conditions in automated thermal cycler are as follows annealing step at $60^{\circ} \mathrm{C}$ for $40 \mathrm{~s}$, extension step at $72^{\circ} \mathrm{C}$ for $40 \mathrm{~s}$, and denaturation step at $95^{\circ} \mathrm{C}$ for $20 \mathrm{~s}$. Negative control reaction was performed without reverse transcriptase for each sample. The electrophoretic was used separate PCR products are each sample for analyse by using DNA-500 or 1000 kit using a Microchip Electrophoresis System-MCE®-202 (Shimadzu, Japan). 
Table 1

product information and primer sequence ( $F-$

Forward, R-Reverse)

\begin{tabular}{|c|c|}
\hline Gene & Primer sequence (5'-3') \\
\hline \multirow[t]{2}{*}{ GAPDH } & F: GGTCACCAGGGCTGCTTTT \\
\hline & R: TTCCCGTTCTCAGCCTTGAC \\
\hline \multirow[t]{2}{*}{ p53 } & F: ССTCCTGGCCСCTGTCATCTT \\
\hline & R: ACCTCCGTCATGTGCTGTGAC \\
\hline \multirow[t]{2}{*}{ Bax } & F: GCCCTTTTCTACTTTGCCAGC \\
\hline & R: TCAGCCCATCTTCTTCCAGAT \\
\hline \multirow[t]{2}{*}{$\mathrm{Bcl} 2$} & F: GGCCTTCTTTGAGTTCGGTGG \\
\hline & R: GATAGGCACCCAGGGTGATGC \\
\hline \multirow[t]{2}{*}{ p21 } & F: GACCAGCATGACAGATTTC \\
\hline & R: TGAGACTAAGGCAGAAGATG \\
\hline
\end{tabular}

\subsection{Western blot}

Initially, HCT-116 cells at the cell density of $1 \times 10^{6}$ were cultured using $100 \mathrm{~mm}$ cell culture dishes using DMEM media in a $\mathrm{CO}_{2}$ incubator for $24 \mathrm{~h}$. Later, the old media was removed and the cells were replenished with fresh culture media containing U-AgNPs. The cells were again incubated for another 24 $\mathrm{h}$ and then harvested by trypsinization. After trypsinization, cells collected were washed twice with icecold $1 \mathrm{X}$ PBS and resuspended in lysis buffer at $4^{\circ} \mathrm{C}$ for $45 \mathrm{~min}$ used for RIA ( $50 \mathrm{mM}$ Tris, $150 \mathrm{mM} \mathrm{NaCl}, 5$ mM EDTA, $0.5 \mathrm{mM}$ deoxycholate, $0.1 \%$ SDS, $1 \%$ NP-40, $1 \mathrm{mM} \mathrm{Na}_{3} \mathrm{VO}_{4}, 1 \mathrm{mM}$ phenyl methane sulphonyl fluoride, $2 \mathrm{mM}$ dl-dithiothreitol, $10 \mathrm{mM}$ b-glycerophosphate, $50 \mathrm{mM} \mathrm{NaF}, 0.5 \%$ Triton X-100 and protease inhibitor cocktail). After the treatment with lysis buffer, the lysate was subjected to centrifugation at $14000 \mathrm{rpm}$. The cell debris as pellet was removed and supernatant collected was used for Bradford method of protein estimation. A 10\% SDS-PAGE was run for the determined protein samples and was transferred to the polyvinylidene difluoride membrane. Finally, the membrane was treated with antibodies of glyceraldehyde-3- phosphate dehydrogenase (GAPDH), Bcl-2, Bax, p53, and p21 as per protocol where GAPDH is used as control.

\section{Results And Discussion}

\subsection{Synthesis and Characterization of U-AgNPs 3.1.1 UV-visible Spectroscopy analysis}


The synthesis of biogenic U-AgNPs was carried by reduction of $\mathrm{AgNO}_{3}$ (aqueous ionic form) into metal nanoparticles (solid). The change in color of the solution from green to dark yellow indicates the formation of U-AgNPs. However, to further confirm the synthesis of nanoparticle formation from plant extract, we performed UV-vis absorption spectroscopy (Fig. 1). The spectra obtained from plant extract, silver nitrate solution, and AgNPs are shown in Fig. 1. While there was no peak observed for the extract and silver nitrate solution, a clear peak at $452 \mathrm{~nm}$ for AgNPs attributes to the surface plasmon resonance of nanoscale metallic silver. Thus, the preliminary confirmation of U-AgNPS was done with SPR peak at $452 \mathrm{~nm}$.

\subsubsection{Fourier-transform infrared spectroscopy (FTIR) analysis}

FTIR analysis of nanoparticles gives the idea about the local environment or change in the functional groups adsorbed on the surface of nanoparticles. The comparative FTIR Spectra of $\mathrm{AgNO}_{3}$, Ulva Lactuca, and U-AgNPs are shown in Fig. 2. The spectrum for aqueous extract of $\mathrm{Ulva}$ Lactuca and $\mathrm{AgNO}_{3}$ shows all the characteristic peaks of the compounds, whereas in the case of the synthesized U-AgNPs the peak at $1474 \mathrm{~cm}^{-1}$ corresponds to the presence of nanoparticles as opposed to $\mathrm{AgNO}_{3}$. Also, as observed from Fig. 2, U-AgNPs exhibits a peak at $3045 \mathrm{~cm}^{-1}$ which points to an existing ester (C-O) bond. The presence of a significant number of secondary metabolites in the aqueous extract of Ulva Lactuca act as reducing agents. The carotenoids and tocopherol are the phytochemicals mainly considered responsible for the reduction of $\mathrm{AgNO}_{3}$ to silver nanoparticles (U-AgNPs). The broadening of amide I band peak at $1984 \mathrm{~cm}^{-}$

1 indicates the capping of U-AgNPs during the synthesis process. This amide I band peak at $1984 \mathrm{~cm}^{-1}$ is attributed to the carbonyl stretch in proteins. whereas the peak at $3387 \mathrm{~cm}^{-1}$ is the characteristic of $\mathrm{OH}$ stretch in alcohol-based compounds. Hence, bioactive molecules of Ulva Lactuca extract presence over the AgNPs surface as capping agent confirmed by FTIR analysis, thereby increasing the surface stability of AgNPs along with enhancing the biocompatibility as well as its anticancer activity $[26,27]$.

\subsubsection{X-ray Diffraction analysis}

The crystalline structure of synthesized U-AgNPs was confirmed with the X-ray Diffraction technique. The results (Fig. 3) show the comparative XRD patterns for plant extract powder, silver nitrate, and U-AgNPs. In Fig. 3, the clear distinct diffraction peaks were observed for U-AgNPs at the respective Bragg's angle

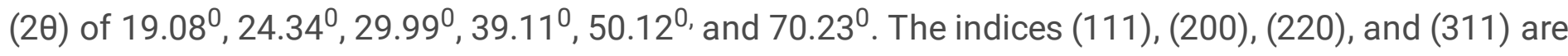
indexed to face-centered cubic (FCC) structure and confirm the crystalline nature of AgNPs following International Center for Diffraction Data, JCPDS 04-0783 [28]. The average crystal size of synthesized UAgNPs was derived from FWHM (full width at half maximum) of the peak corresponding to 111 planes and was found to be $5.63 \mathrm{~nm}$.

\subsubsection{Z-potential}


The net surface charge or $\zeta$-potential of U-AgNPs was determined using a Zeta analyzer. From Fig. 4, it could be said that synthesized U-AgNPs are positively charged with a surface potential of $+12.5 \pm 2.2 \mathrm{mv}$. This positive surface potential on U-AgNPs can be attributed to the effective coating of Ulva-Lactuca and confirms the stability of U-AgNPs.

\subsubsection{TEM and DLS analysis}

The morphological features of synthesized U-AgNPs were analysed using TEM and DLS particle size analyzer. As observed from Fig. $5 \mathrm{~A}$ and $\mathrm{B}$, the particles obtained are spherical with sizes ranging between 8-14 nm. Whereas, the hydrodynamic size of U-AgNPs using DLS analysis was found to be in the range of 10-20nm (Fig. 5D). Furthermore, the electron diffraction pattern (SAED) of the AgNPs indicates the crystalline nature of nanoparticles, which confirms the XRD data (Fig. 3).

\subsection{Effect of U-AgNPs on cell proliferation of colon cancer cells}

\subsubsection{Cell-viability assay}

The cell viability of HCT-116 cells was examined in presence of U-AgNPs, $\mathrm{AgNO}_{3}$, and Ulva Lactuca extract via MTT assay and colony-forming ability of cells. For the clonogenic assay, HCT-116 cells were treated separately with U-AgNPs, $\mathrm{AgNO}_{3}$, and Ulva Lactuca extract for $24 \mathrm{~h}$. The results (Fig. 6A) indicate a dose-dependent cell death in presence of U-AgNPs and $\mathrm{AgNO}_{3}$, respectively. From Fig. $6 \mathrm{~A}$ it is clear that at a concentration of $200 \mu \mathrm{M}, \mathrm{U}-\mathrm{AgNPs}$ and $\mathrm{AgNO}_{3}$ caused cell death of $90 \%$ and $35 \%$ respectively. However, there was no significant effect seen on the viability of HCT-116 in presence of Ulva Lactuca extract. Hence, we demonstrated that synthesized U-AgNPs exhibit higher antiproliferative potential against HCT-116 cells as compared to its precursor compounds viz. $\mathrm{AgNO}_{3}$ and Ulva Lactuca extract (Fig. 6A). Moreover, the $\mathrm{IC}_{50}$ value of HCT-116 cells treated with U-AgNPs, were derived from Fig. $6 \mathrm{~B}$ and it was found to be $142 \pm 0.45 \mu \mathrm{M}$. This concludes that U-AgNPs are mitigating the cell attachment to form the colony as compared to the $\mathrm{AgNO}_{3}$ and Ulva Lactuca extract.

MTT assay was carried out to further validate the findings of the clonogenic assay. As observed from Fig. 6B, a dose-dependent cell death in HCT-116 cells occurred with the cells treated with U-AgNPs. The cell death was found to be $85 \%$ with U-AgNPs as compared to the $23 \%$ with $\mathrm{AgNO}_{3}$, for the same concentration $(200 \mu \mathrm{M})$ after $24 \mathrm{~h}$ of treatment. Hence to further explore the underlying mechanisms attributing the cytotoxic behaviour of U-AgNPs against HCT-116 cells, we chose to work with lower UAgNPs concentration of 50,100 , and $200 \mu \mathrm{M}$.

However, with the anticancer effects of U-AgNPs, it becomes imperative to examine the cytocompatibility of U-AgNPs using a normal human epithelial cell line. Hence, the effect of U-AgNPs was studied in both normal human epithelial cell line (FHC cells) as well as in colon cancer HCT-116 cell lines using varying 
concentrations $(0-1000 \mu \mathrm{M})$ of U-AgNPs for $24 \mathrm{~h}$ and cell viability was measured. The results indicate only a $20 \%$ loss of cell viability in normal human epithelial cell line (FHM) cells as compared to that colon cancer cell line HCT-116, which was found to be almost $95 \%$ at the same U-AgNPs concentration (Fig. 6C). There was a drastic decrease in cell viability of HCT-116 cells at the minimum starting concentration of U-AgNPs, which further reduced as the dose of AgNPs was increased. However, in the case of FHM cell lines, the cell viability was not affected as much and does not affect higher doses of AgNPs with an overall $20 \%$ decrease in viability (Fig. 6C). This difference in cell viability of FHM and HCT cell lines in presence of U-AgNPs confirms the selective toxicity of U-AgNPs against the cancer cell line while keeping the normal human epithelial cell line unaffected.

\subsubsection{Nuclear staining assay}

Apoptosis helps in maintaining the balance between healthy and unhealthy cells inside the human body, by successfully removing the defective cells from the body. Hence to understand the mechanism behind the antiproliferative activity of U-AgNPs against colon cancer cell lines, we performed a nuclear staining assay using Hoechst 33342 dye. The Hoechst 33342 dye binds to the DNA and emits blue fluorescence under UV illumination. This helps to visualize and analyze the nuclear morphology of the cell and determine any defect in cell morphology. The fluorescence micrographs of AgNPs treated cells stained with Hoechst 33342 dye were obtained and the DNA of cells treated with AgNPs is fragmented and significant nucleus condensation was quite visible, whereas the morphology of untreated cell was found intact (Fig. 7). Further, we also found that the fragmentation and distorted morphology of the cell becomes much clearer and enhanced with the increased AgNPs in concentration (Fig. 7). As nuclear condensation and cell fragmentation are major indications of apoptosis-led cell death, we can assume that U-AgNPs treatment also leads to cancer cell death through apoptosis.

\subsubsection{Apoptosis-Associated mRNA and Protein Expression}

To confirm the apoptosis mediated cell death by U-AgNPs in the cancer cell, we examined the mRNA levels of apoptosis markers in HCT-116 cells after treatment with U-AgNPs where anti-apoptotic (Bcl-2) as well as pro-apoptotic markers (P53, Bax, and P21) were determined against GAPDH as control (Fig. 8). The RT-PCR analysis of changes in mRNA levels in cells treated with different concentrations of U-AgNPs $(0-200 \mu \mathrm{M})$ was recorded. It was observed that anti-apoptotic makers Bcl2 levels were high in untreated cells or control sample, but the expression level of $\mathrm{Bcl} 2$ found to decreased with increasing concentration of U-AgNPs. On the other hand, P53, Bax, and P21 showed significantly upregulated expression after the treatment with U-AgNPs. The upregulation in the expression of these markers was shown to be dosedependent (Fig. 8) confirming the selective anticancer activity of U-AgNPs via p53-dependent apoptosis against the colon cancer cell line [29].

Further, we performed western blot to determine expression level of anti-apoptotic and pro-apoptotic markers in HCT cells after treatment with U-AgNPs where the expression of glyceraldehyde-3- phosphate dehydrogenase (GAPDH) is used as a control (Fig. 9). As observed from Fig. 9, at lower U-AgNPs 
concentration $(50 \mu \mathrm{M})$ no significant change in protein expression level in all the apoptotic markers was observed. However, with an increase in the concentration of U-AgNPs, while there was an enhancement in the phosphorylation level of the P38 protein, the ERK protein expression showed an insignificant change. Also, the expression level of pro-apoptotic markers P53, Bax, and P21 proteins saw a significant rise whereas anti-apoptotic marker Bcl-2 showed a decline in expression level.

The results obtained confirms that U-AgNPs promotes the increase in phosphorylation levels of P38 protein without significant effects on ERK, thereby promoting the upregulation of pro-apoptotic markers P53 and Bax with the down-regulation of pro-apoptotic markers Bcl-2 leading to the increase in the ratio of Bax/Bcl-2 and activation of P21 resulting in further increase cell death. Moreover, Gopinath et al. (2010) have reported that Bax acts on voltage-dependent ion channels on mitochondria, thereby activating cytochrome-C release and promoting apoptosis [30]. Furthermore, Shahbazzadeh et al ., (2011) have reported that cytotoxic of nano-silver on osteoblast G292 cancer cell line mediated by up-regulation of pro-apoptotic P53 which in-turn activates the transcription of P21 gene resulting in impeding the DNA replication and inhibiting cell proliferation by stopping the cell cycle at the $G 1, G 2$ or S phase [31]. Hence, the cytotoxic effect of AgNPs on HCT-116 cells is dose-dependent and induce via p53-dependent apoptosis. Furthermore, the mechanism of cytotoxicity findings provide necessary toxicological information for developing the better biological safety of nanomaterials for clinical application.

\section{Conclusion}

The current work demonstrated the synthesis of silver nanoparticles (U-AgNPs) by using a green macroalgal Ulva Lactuca and established its selective anticancer activity via p53-dependent apoptosis against the colon cancer cell line (HCT-116) using various biochemical assays such as cell viability using MTT assay, Clonogenic cell survival assay, DAPI nucleus staining as well as western blotting where the expression level of various proapoptotic proteins and anti-apoptotic proteins were determined. U-AgNPs showed dose-dependent and specific cytotoxicity in HCT-116 confirmed by cell viability assay as no effect was seen in human colon epithelial cells. Further, nuclear staining assay confirmed the dosedependent toxicity caused by B-AgNPs in HCT-116 cells via apoptosis. western blotting results demonstrated the increased expression of pro-apoptotic marker P53, Bax, and P21 against GAPDH agent, a housekeeping gene as control whereas Moreover, anti-apoptotic marker proteins expression (Bcl-2) showed a dose-dependent decrease with increase in the U-AgNPs concentration used for treatment. Thus, categorically prove that biogenically synthesised U-AgNPs mediate p53-dependent apoptosis in colon cancer cells HCT-116 via activation of proapoptotic proteins with and inhibition anti-apoptotic proteins via DNA damage. Hence, we categorically proved that biogenically silver nanoparticle (U-AgNPs) prepared using Ulva Lactuca extract is not only an eco-friendly technique, perhaps also possesses anticancer activity potential making it a probable nanotherapeutic for colon cancer with understanding the underlying biological mechanism toxicity in cancer cells inducing apoptosis provides better clinical safety. 


\section{Declarations}

\section{Acknowledgment}

The authors would like to extend their sincere appreciation to the Director of NRME Research Laboratory, Newredmars Education Pvt Ltd for allowing to carry out the research work. The authors sincerely thank the Karunya Institute of Technology and Sciences (Deemed-to-be University for their support, encouragement, and extending all the necessary facilities in the university.

\section{References}

1. S. Gurunathan, M. Qasim, C. Park, H. Yoo, J.-H. Kim, K. Hong, Cytotoxic potential and molecular pathway analysis of silver nanoparticles in human colon cancer cells HCT116. Int. J. Mol. Sci. 19, 2269 (2018)

2. A. Fulfager, K.S. Yadav, Understanding the implications of co-delivering therapeutic agents in a nanocarrier to combat multidrug resistance (MDR) in breast cancer. Journal of Drug Delivery Science and Technology. 2021:102405

3. A.-M. Florea, D. Büsselberg, Cisplatin as an anti-tumor drug: cellular mechanisms of activity, drug resistance and induced side effects. Cancers 3, 1351-1371 (2011)

4. P. Somu, S. Paul, Protein assisted one pot controlled synthesis of monodispersed and multifunctional colloidal silver-gold alloy nanoparticles. J. Mol. Liq. 291, 111303 (2019)

5. J. Zhang, R. Misra, Nanomaterials in microfluidics for disease diagnosis and therapy development. Mater. Technol. 34, 92-116 (2019)

6. H. Bagur, C.C. Poojari, G. Melappa, R. Rangappa, N. Chandrasekhar, P. Somu, Biogenically Synthesized Silver Nanoparticles Using Endophyte Fungal Extract of Ocimum tenuiflorum and Evaluation of Biomedical Properties. Journal of Cluster Science. 2019:1-15

7. K.K. Yadav, M. Arakha, B. Das, B. Mallick, S. Jha, Preferential binding to zinc oxide nanoparticle interface inhibits lysozyme fibrillation and cytotoxicity. Int. J. Biol. Macromol. 116, 955-965 (2018)

8. M. Abd Elkodous, G.S. El-Sayyad, I.Y. Abdelrahman, H.S. El-Bastawisy, F.M. Mosallam, H.A. Nasser et al., Therapeutic and diagnostic potential of nanomaterials for enhanced biomedical applications. Colloids Surf., B 180, 411-428 (2019)

9. P. Chaudhary, F. Fatima, A. Kumar, Relevance of nanomaterials in food packaging and its advanced future prospects. J. Inorg. Organomet. Polym Mater. 30, 5180-5192 (2020)

10. P. Somu, S. Paul, A biomolecule-assisted one-pot synthesis of zinc oxide nanoparticles and its bioconjugate with curcumin for potential multifaceted therapeutic applications. New J. Chem. 43, 11934-11948 (2019)

11. D. Acharya, S. Satapathy, P. Somu, U.K. Parida, G. Mishra, Apoptotic effect and anticancer activity of biosynthesized silver nanoparticles from marine algae chaetomorpha linum extract against human colon cancer cell HCT-116. Biological Trace Element Research. 2020:1-11 
12. F.-D. Cojocaru, D. Botezat, I. Gardikiotis, C.-M. Uritu, G. Dodi, L. Trandafir et al., Nanomaterials designed for antiviral drug delivery transport across biological barriers. Pharmaceutics 12, 171 (2020)

13. L. Carson, S. Bandara, M. Joseph, T. Green, T. Grady, G. Osuji et al., Green Synthesis of Silver Nanoparticles with Antimicrobial Properties Using Phyla dulcis Plant Extract (Foodborne Pathogens and Disease, 2020)

14. C.A. Das, V.G. Kumar, T.S. Dhas, V. Karthick, K. Govindaraju, J.M. Joselin et al., Antibacterial activity of silver nanoparticles (biosynthesis): A short review on recent advances. Biocatalysis and Agricultural Biotechnology. 2020:101593

15. H. Bagur, R.S. Medidi, P. Somu, P.J. Choudhury, C.S. karua, P.K. Guttula et al., Endophyte fungal isolate mediated biogenic synthesis and evaluation of biomedical applications of silver nanoparticles. Materials Technology. 2020:1-12

16. K.S. Siddiqi, A. Husen, R.A. Rao, A review on biosynthesis of silver nanoparticles and their biocidal properties. Journal of nanobiotechnology 16, 14 (2018)

17. S. Deshmukh, S. Patil, S. Mullani, S. Delekar, Silver nanoparticles as an effective disinfectant: A review. Materials Science and Engineering: C 97, 954-965 (2019)

18. D. Acharya, S. Satapathy, J.J. Thathapudi, P. Somu, G. Mishra, Biogenic synthesis of silver nanoparticles using marine algae Cladophora glomerata and evaluation of apoptotic effects in human colon cancer cells. Materials Technology. 2020:1-12

19. L. Wang, T. Zhang, P. Li, W. Huang, J. Tang, P. Wang et al., Use of synchrotron radiation-analytical techniques to reveal chemical origin of silver-nanoparticle cytotoxicity. ACS Nano 9, 6532-6547 (2015)

20. C. Marambio-Jones, E.M. Hoek, A review of the antibacterial effects of silver nanomaterials and potential implications for human health and the environment. J. Nanopart. Res. 12, 1531-1551 (2010)

21. S. Mahanta, S. Prathap, D.K. Ban, S. Paul, Protein functionalization of ZnO nanostructure exhibits selective and enhanced toxicity to breast cancer cells through oxidative stress-based cell death mechanism. J. Photochem. Photobiol., B 173, 376-388 (2017)

22. J.H. Ahire, M. Behray, C.A. Webster, Q. Wang, V. Sherwood, N. Saengkrit et al., Synthesis of carbohydrate capped silicon nanoparticles and their reduced cytotoxicity, in vivo toxicity, and cellular uptake. Advanced healthcare materials 4, 1877-1886 (2015)

23. E. Panzarini, S. Mariano, C. Vergallo, E. Carata, G.M. Fimia, F. Mura et al., Glucose capped silver nanoparticles induce cell cycle arrest in HeLa cells. Toxicology In Vitro 41, 64-74 (2017)

24. R. Kalaiarasi, N. Jayallakshmi, P. Venkatachalam, Phytosynthesis of nanoparticles and its applications. Plant Cell Biotechnology and Molecular Biology 11, 1-16 (2010)

25. O.V. Kharissova, H.R. Dias, B.I. Kharisov, B.O. Pérez, V.M.J. Pérez, The greener synthesis of nanoparticles. Trends in biotechnology 31, 240-248 (2013) 
26. S. Trivedi, M.A. Alshehri, C. Panneerselvam, H.A. Al-Aoh, F. Maggi, S. Sut et al., Insecticidal, antibacterial and dye adsorbent properties of Sargassum muticum decorated nano-silver particles. South African Journal of Botany 139, 432-441 (2021)

27. N. Khatoon, J.A. Mazumder, M. Sardar, Biotechnological applications of green synthesized silver nanoparticles. J Nanosci Curr Res 2, 107 (2017)

28. A.J. Adur, N. Nandini, K.S. Mayachar, R. Ramya, N. Srinatha, Bio-synthesis and antimicrobial activity of silver nanoparticles using anaerobically digested parthenium slurry. J. Photochem. Photobiol., B 183, 30-34 (2018)

29. M. Fernandez, R. Munoz-Olivas, J. Luque-Garcia, SILAC-based quantitative proteomics identifies sizedependent molecular mechanisms involved in silver nanoparticles-induced toxicity. Nanotoxicology 13, 812-826 (2019)

30. P. Gopinath, S.K. Gogoi, P. Sanpui, A. Paul, A. Chattopadhyay, S.S. Ghosh, Signaling gene cascade in silver nanoparticle induced apoptosis. Colloids Surf., B 77, 240-245 (2010)

31. D. Shahbazzadeh, H. Ahari, A. Motalebi, A. Anvar, S. Moaddab, T. Asadi et al., In vitro effect of Nanosilver toxicity on fibroblast and mesenchymal stem cell lines. Iranian Journal of Fisheries Sciences 10, 487-496 (2011)

\section{Figures}

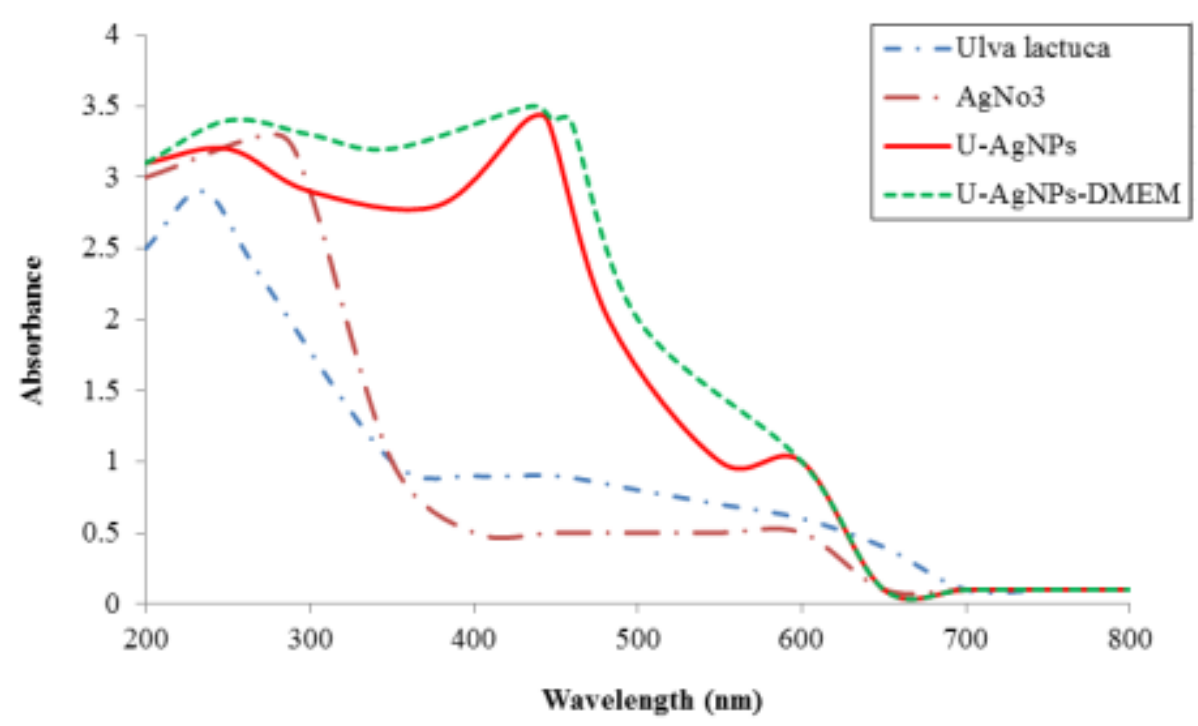

\section{Figure 1}

UV-vis absorption spectrum of Ulva Lactuca Extract (blue dashed line), AgNO3 solution (red dashed line), U-AgNPs in water (red solid line), and U-AgNPs in cell culture media (Green dashed line). 


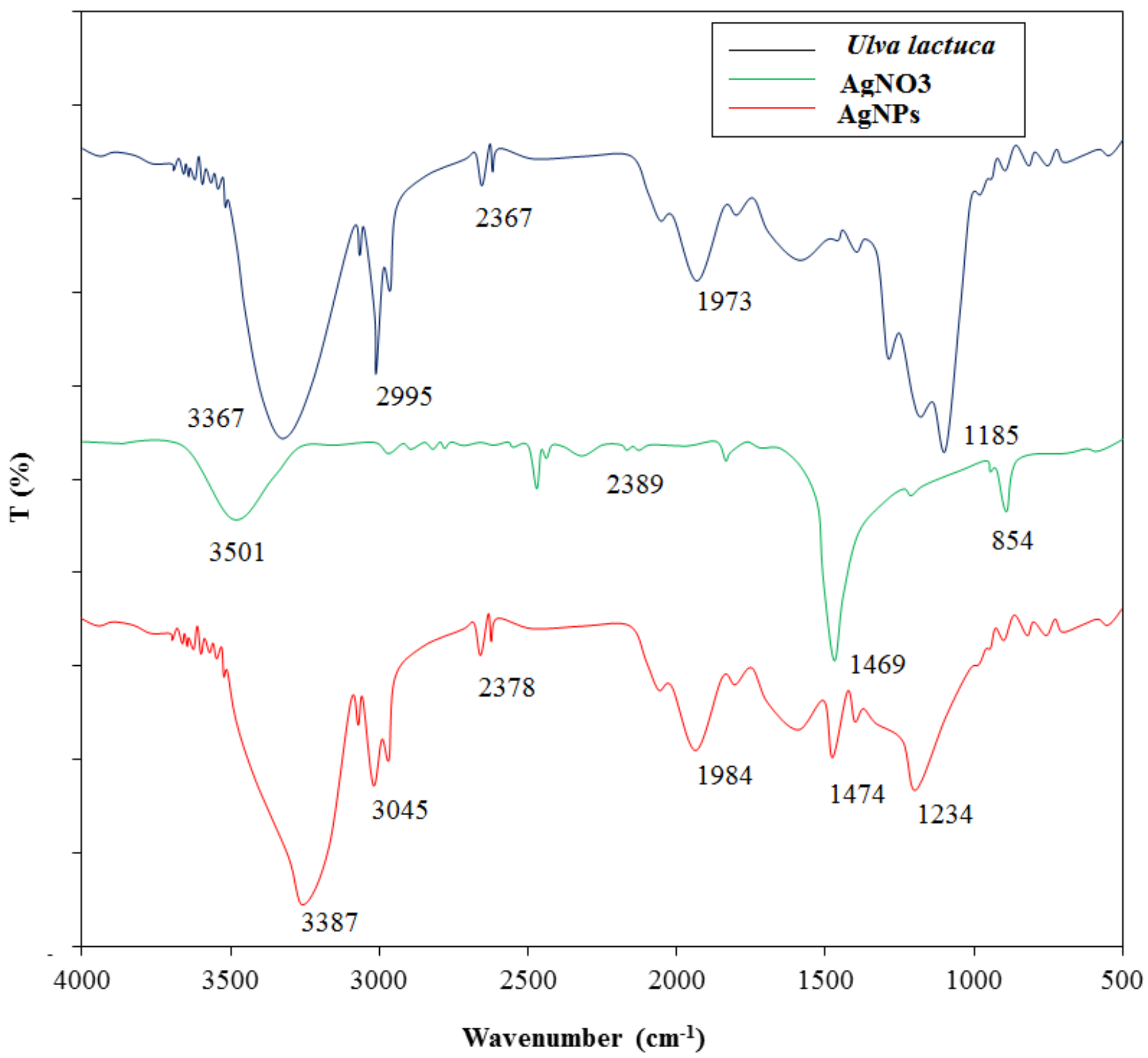

Figure 2

FT-IR spectra of Ulva Lactuca extract (black line) agno3 green line) U-AgNPs (red line) 


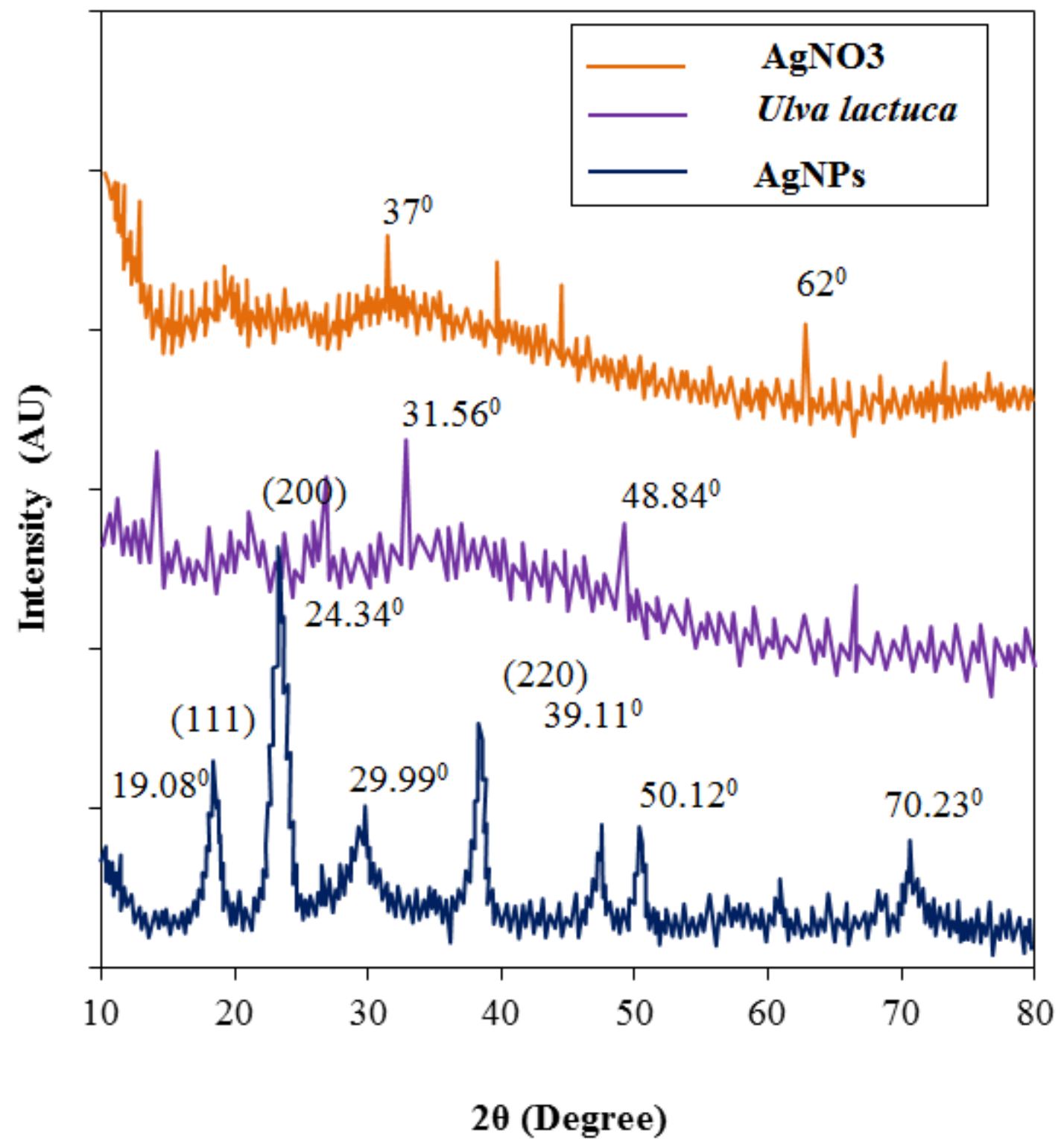

Figure 3

XRD pattern of AgNO3 (orange line), Ulva lactuca (purple line) and U- AgNPs (blue line) 


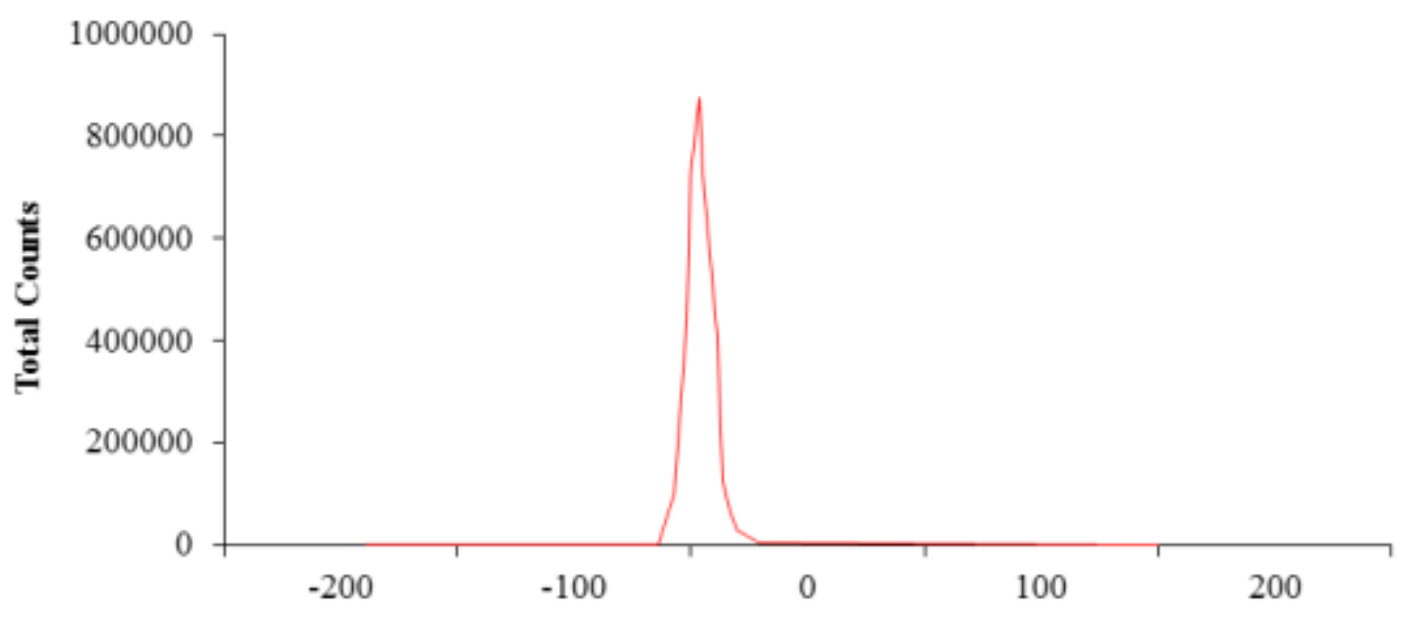

\section{Zeta-potential (mV)}

\section{Figure 4}

Zeta potential of U-AgNPs

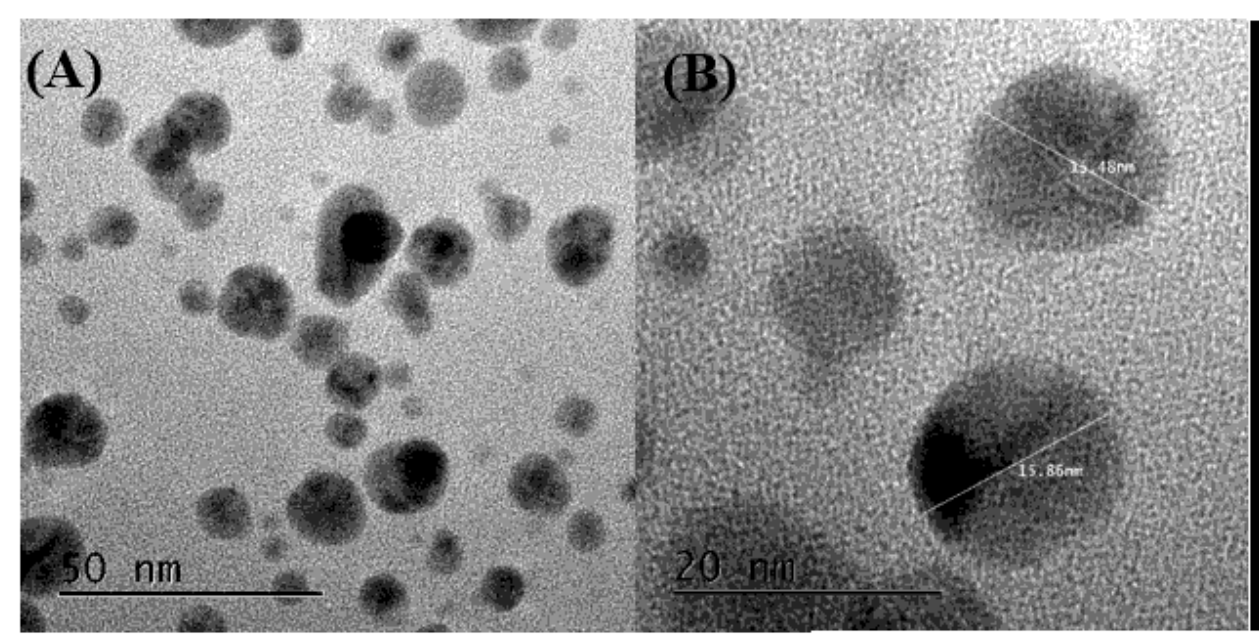

\section{(C)}

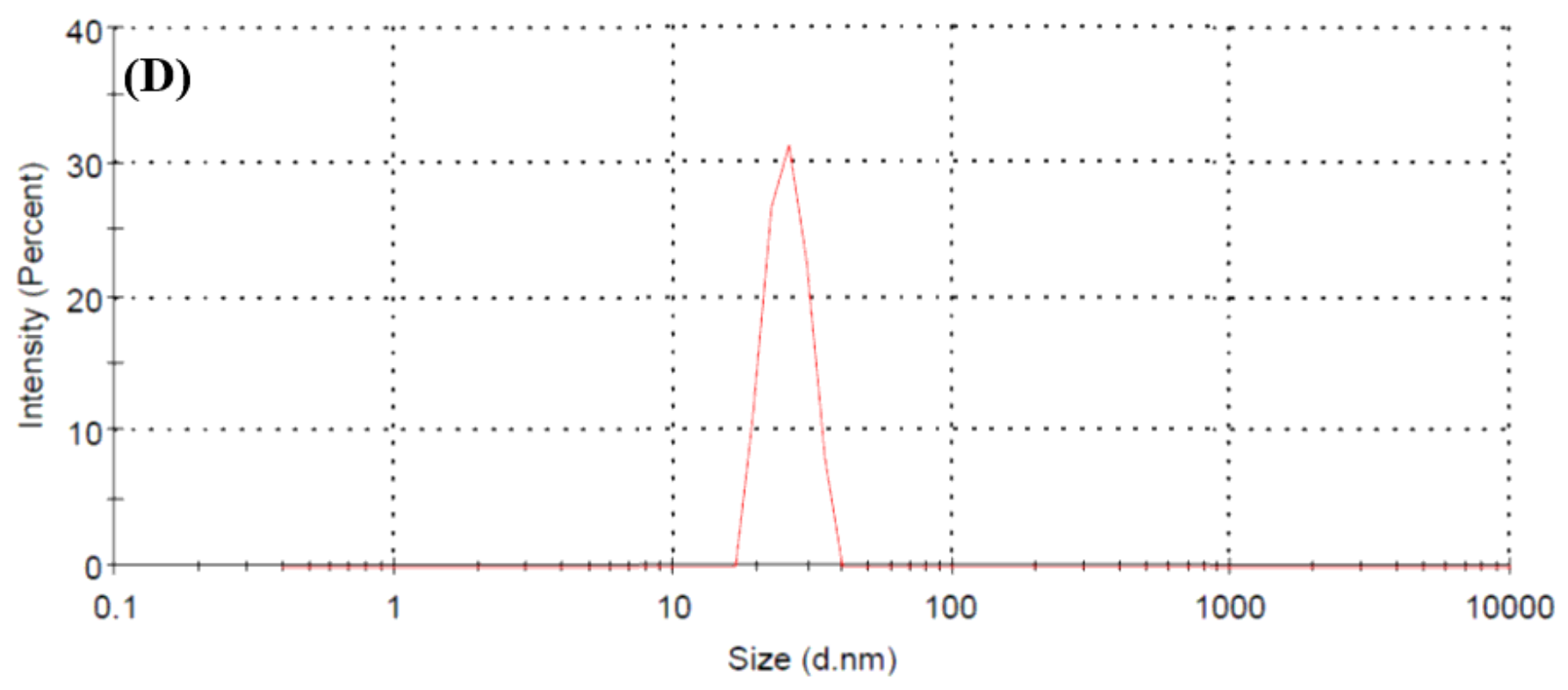

Figure 5 
(A) and (B)TEM micrographs of U-AgNPs. (C) SAED pattern and (D) DLS analysis of U-AgNPs.
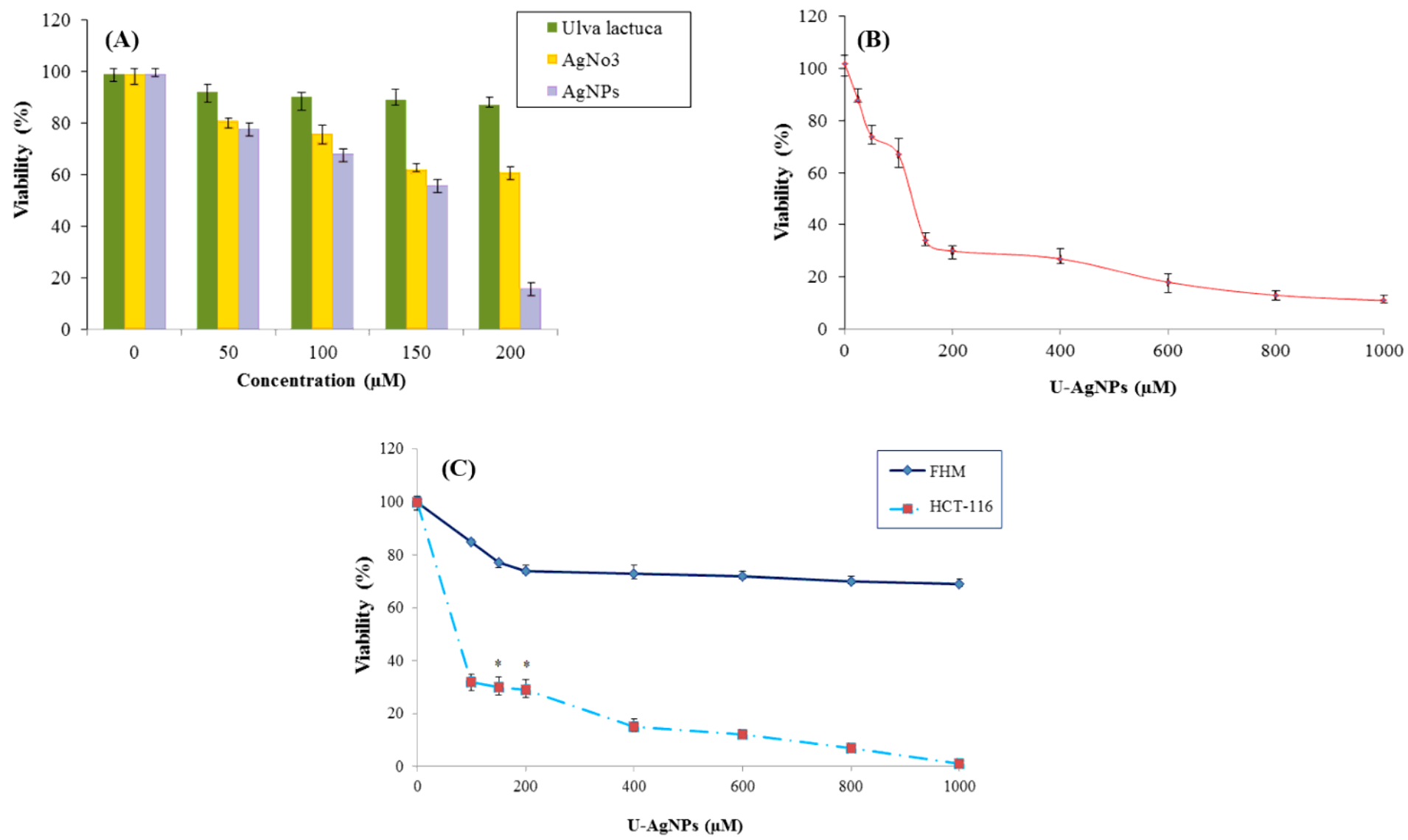

Figure 6

Clonogenic assay against HCT116 cells. (A) Comparative graph showing the percentage of cell viability concerning the concentration of Ulva Lactuca (green), AgNO3 (yellow), and U-AgNPs (grey). (B)

Percentage viable cells of HCT- 116 cell $24 \mathrm{~h}$ post-treatment with increasing concentrations of U-AgNPs. The maximum cell death occurs as the concentration of U-AgNPs increases. (C) A comparative plot of cell viability (\%) of cancer HCT-116 and normal FHM cell lines when treated with varying concentrations of U-AgNPs. Data obtained in triplicates are shown as mean \pm standard deviation and represent the significance value , ${ }^{\star} \mathrm{p}<0.05$ as determined by paired t-test. AgNPs: Silver nanoparticle; FHM: normal human epithelial cell line. 
100

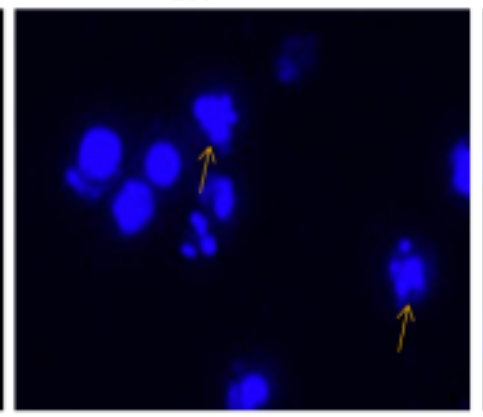

200

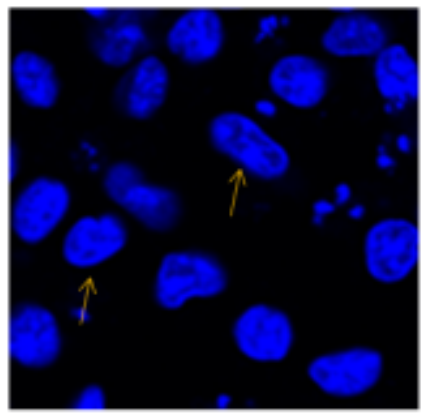

Figure 7

Demonstration of U-AgNPs led to apoptosis in HCT-116 cells. Cells treated with 0,50100 , and $200 \mu \mathrm{m}$ of AgNPs for 48 h, were stained with Hoechst 33342 dye. The panels show the blue fluorescence observed under UV light and cell morphology can be visualized. The arrows in the three images indicate the presence of fragmented/dead cells that have undergone apoptosis.

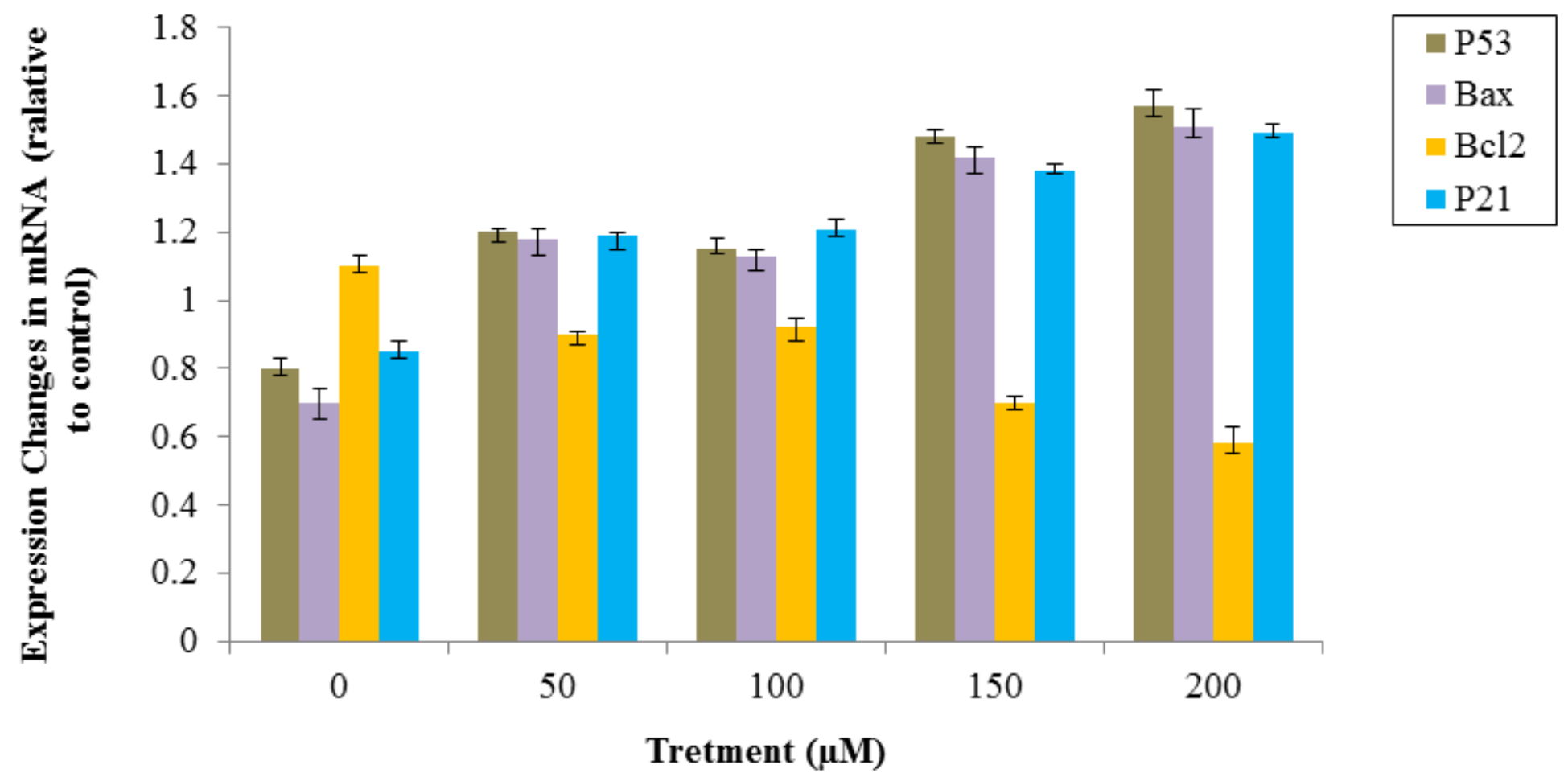

\section{Figure 8}

Analysis of mRNA expression of apoptosis marker genes in HCT-116 colon cancer cells post U-AgNPs treatment $(0-200 \mu \mathrm{M})$. The experiment was performed in triplicates and data represent mean. * means $p<$ $0.05 ; * \star$ means $p<0.01$. 
Concentration of U-AgNPs $(\mu \mathrm{M})$

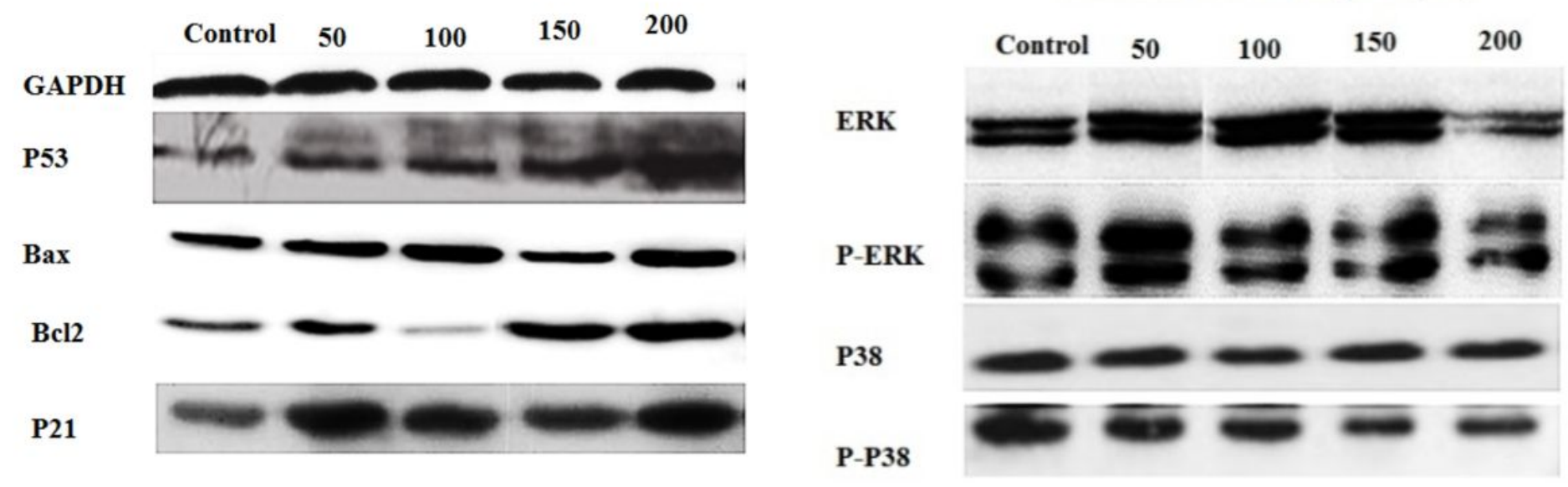

\section{Figure 9}

Western blot analysis of the expression changes in the protein level of GAPDH, P53, Bax, Bcl-2, P21, ERK, P-ERK, P-38, and PP-38 after exposure to U-AgNPs for HCT-116 cells. 